\title{
Economic Determinants of Unemployment in Malaysia: Short - and Long - Run Causality
}

\author{
Jason Freedline Baba \\ Faculty of Economics and Business \\ Universiti Malaysia Sarawak, 94300 Kota Samarahan, Sarawak, Malaysia \\ Dayang Haszelinna binti Abang Ali (Corresponding author) \\ Centre for Policy Research and International Studies, Universiti Sains Malaysia \\ 11800 USM, Penang, Malaysia
}

Received: Oct. 10, 2020 Accepted: Feb. 19, 2021 Online published: Mar. 11, 2021

doi:10.5296/jpag.v11i1.17794 URL: https://doi.org/10.5296/jpag.v11i1.17794

\begin{abstract}
The problem of unemployment has become a worrisome issue over the past few years as it is growing at an alarming state in many countries throughout the world particularly in developing countries such as Malaysia. There are numerous factors that cause this phenomenon. Therefore, the aim of this study is to empirically investigate the determinants of unemployment in Malaysia as well as the relationship between unemployment and the chosen fundamental macroeconomic factors such as gross domestic product, foreign direct investment, inflation, and population. This study utilized the annual time series data of 31 year period starting from the year 1985 to the year 2015. The methodology of econometric analysis have been applied in this study such as unit root tests, co-integration test, vector error correction model, variance decompositions, and impulse response functions analysis. The findings showed that there are presences of short run causality among the variables and also a presence of long run only when population act as the dependent variable in the model. Besides, the findings indicate that GDP has a significant negative impact whereas FDI has a significant positive impact on unemployment in Malaysia. Overall, the conclusion of this study suggests that demand side policies and supply side policies are the most excellent and suitable approach in overcoming the problem of unemployment in Malaysia.
\end{abstract}

Keywords: unemployment Malaysia, short run, long run, FDI, VECM 


\section{Introduction}

\subsection{Scenario of Human Resources in Malaysia}

Malaysia has implemented productivity-enhancing reforms to accelerate the increase of quality human resources and competitiveness in the economy as a key to secure a long-lasting place amongst the ranks of high income economies. Furthermore, the New Economic Model (NEM) has been launched in 2010, with the aim to reach a status of high income country by the year 2020 while ensuring that the economic growth is inclusive and sustainable (Economic Planning Unit, 2011). In a year, approximately 200,000 students graduate from institutions of higher learning were not able to find a job which worsen the number of persons unemployed This is due to the fact that they don't have enough working experience and certain quality to fulfil the labor market's requirement (Hanapi \& Nordin, 2014). Furthermore, the uncontrollable entry of foreign workers into the country has increased the rivalry for employment. Zaleha, Noraini, Rusmawati, and Suhaila (2011) mentioned that Malaysian workers would likely to avoid working in a dirty, dangerous, and difficult job which is also known as the 3D's, which causing themselves to be unemployed even though they already have the opportunity to be employed.

\subsection{Significance of Study}

There seems to be an obvious upward trend since the end of 2014, despite the fact that the unemployment rate in Malaysia tend to be volatile around 3.0\% to 3.2\% (MIDF Research, 2016). According to the Department of Statistics Malaysia (2016), the number of persons unemployed had since rose from 0.45 million in November to 0.47 million in December of 2015 , even with the high participation rate of labor force which is at $67.8 \%$. Concisely, these were the main reasons that caused the number of persons unemployed in Malaysia to keep on increasing year by year.

This motivates the study of unemployment as it help to depict the health of an economy on a local, state, and national scale. The presence of unemployment in a country, if uncontrollable, can cause losses of income, increases expenditure, and societal problems (Burns, 1969). These are also known as dead losses as the costs caused by unemployment do not generate any gains or benefits to the country. A significant lost towards the country will occur due to this serious matter. Hence, it is important to recognize the fundamental factors that affect the problem of unemployment because it primarily serves as a measurement of the economy's health.

\subsection{Literature Review}

Okun's law, which was proposed by American economist Arthur Okun in 1962, describes one of the most famous empirical relationships in macroeconomics. Okun (1962) has found that there is an inverse relationship between unemployment and GDP. Sahin et al (2014) found a similar relationship in China. The law essentially states that the unemployment rate declines if GDP grows rapidly. A decrease of $1 \%$ in unemployment will increase the potential GDP for approximately $3 \%$. However, if the growth rate of GDP is pessimistic or very low then the unemployment rate rises and if the growth rate of GDP is equal to potential level then the 
unemployment rate remains unaffected. Some previous studies contradict with Okun's law (Prachowny, 1993; Blinder, 1997; Altig, Fitzgerald, \& Rupert, 1997). Their study found that there is a positive relation between GDP and unemployment. Changes in output are correlated with labor's productivity thus it is dispensed in Okun's study. There are various factors that influenced the changes in labor's productivity such as improvements in technology which happened in the US and other western countries. Moreover, it can also be due to an increase in the quality of labor such as education, skills, and working overtime. All of these factors can cause GDP to rise but it does not necessarily able to reduce unemployment. Kreishan (2011) examined the relationship between economic growth and unemployment through the implementation of Okun's law in Jordan, covering the period of 1970 to 2008. Techniques of time series were used to obtain the estimation for Okun's coefficient and to test the relationship between economic growth and unemployment. Specifically, Augmented Dickey-Fuller (ADF) for unit root test, Co-integrating Regression Durbin-Watson (CRDW), and a simple regression between economic growth and unemployment were used. His findings revealed that Okun's law cannot be established in Jordan. Hence, it suggested that the problem of unemployment cannot be explained by lack of economic growth in Jordan. In Indonesia, Trimurti and Komalasari (2014) also found there is no significant impact of GDP on unemployment.

Rafiq, Ahmad, Ullah, and Khan (2009) reviewed on the determinants of unemployment in Pakistan's economy by using time series data between the year 1998 and 2008. The technique of Ordinary Least Squares (OLS) and Simple Single Equation Linear Regression Model (SELRM) is applied in their study. They concluded that there is a positive relationship between unemployment and population while FDI has a negative effect on unemployment. The similar result was found by El-Agrody, Othman and Hassan (2010) in Egypt, Shaari, Hussain and Halim (2012) in Malaysia, and Mpanju (2012) in Tanzania.

On the other hand, Mucuk and Demirsel (2013) focused on the relationship between FDI and unemployment by implementing the technique of panel data analysis for 7 developing countries, which were Uruguay, Turkey, Thailand, Philippines, Colombia, Chile, and Argentina from the period of 1981 until 2009. Panel co-integration, panel unit root, and panel causality tests were conducted on the data collected. Their study shows that FDI and unemployment shift together in the long run. However, even though FDI increases unemployment in Argentina and Turkey, it reduces unemployment in Thailand. Causality tests depicted that there is a relationship from FDI to unemployment only in the long run.

Subhani and Osman (2011) investigated on the South Asian Phillips curve. By applying simple regression analysis and using annual data from the year 1981 until 2010, they found that there is a negative relationship between inflation and unemployment for the country Bangladesh while the relationship is positive for Pakistan. This result also supported by a study of Umair and Ullah (2013), where their results revealed that the correlation between inflation and unemployment is positive, however insignificant at $10 \%$ level of significance. On the other hand, India and Sri Lanka showed no relationship between inflation and unemployment. In the case of China, there is insignificant relation between inflation and unemployment as of study by Sahin (2014). 
Ali, Ali, and Amin (2013) examined the impact of population growth on economic development in Pakistan within the period of 1975 to 2008. The relationship between population and economic development was investigated using the method of Autoregressive Distributed Lag (ARDL). Their findings revealed that although the impact of population growth is positive on economic development, however it is negative on unemployment. Moreover, the creation of unemployment caused by population growth led to the lacking of health and educational facilities. They suggested the government to form a policy to utilize all additional work forces competently to attain the desired growth level. Maqbool, Sattar, and Bhalli (2013), and Sabir and Naz (2015) also study the determinants of unemployment in Pakistan and they found that the population was positive and significant in contributing the problem of unemployment. Moreover, it was also revealed that GDP was positive however insignificant while inflation was negative but significant in causing unemployment.

\subsection{Scope of Study}

Malaysia, like a number of developing countries, encountered unemployment and it has been one of the major problems due to the lack of absorption capacity. The issue of unemployment which occurs in developing countries is one of the most important issues that differentiate it from those of the developed countries. If the excessive rate of unemployment continues, it will have a negative impact on the economy which causes the economic conditions to be unstable which had been seen during the financial crisis in 1997 and 2008 where the economy was slowing down. The problem of unemployment is troublesome because there is an under-utilization of resources when workers are unemployed which consequently affecting the total production of a country to be less than its potential level of output. Hence, it is important to recognize the fundamental factors that affect the problem of unemployment because it primarily serves as a measurement of the economy's health. Thus, this study tends to examine the relationship between selected macroeconomic variables in both short and long run.

\section{Method}

\subsection{Data}

The collection of data in this study involves the process of reviewing the previous researches on how the variables related and influenced one another. In addition, this study will be using time series data for the period of 31 years starting from the year 1985 until the year 2015 annually. All the data used in this study are collected from Computer Enterprise Investigations Conference (CEIC) database, The World Bank Data Bank, and The Department of Statistics Malaysia. The dependent variable of this study is unemployment (UNEM) while gross domestic product (GDP), foreign direct investment (FDI), inflation (INF), and population (POP) will be the independent variables. The description of the data is given in Table 1 below: 
Table 1. Data Descriptions

\begin{tabular}{|c|c|}
\hline Variables Used & Descriptions \\
\hline Unemployment (UNEM) & $\begin{array}{l}\text { - Unemployment measured by person, which represent individuals } \\
\text { who are unemployed but actively seeking for employment and } \\
\text { willing to work. } \\
\text { - Unit is in million. }\end{array}$ \\
\hline $\begin{array}{lll}\text { Gross } & \text { Domestic } & \text { Product } \\
\text { (GDP) } & & \end{array}$ & $\begin{array}{l}\text { - GDP measured by the nominal GDP, which represent the } \\
\text { measure of the value of all final goods and services produced } \\
\text { during a particular period. } \\
\text { - GDP is expected to have a negative impact on unemployment. } \\
\text { - Unit is in US dollars (million). }\end{array}$ \\
\hline $\begin{array}{l}\text { Foreign } \quad \text { Direct } \\
\text { (FDI) }\end{array}$ & $\begin{array}{l}\text { - FDI represents an investment made by a company from another } \\
\text { country which has control over the company purchased. } \\
\text { - FDI is expected to have a negative influence on unemployment, } \\
\text { such as generating more jobs which boost a country's economic } \\
\text { growth. } \\
\text { - Unit is in percentage. }\end{array}$ \\
\hline Inflation (INF) & $\begin{array}{l}\text { - Inflation measured by the unlimited increase of general price } \\
\text { level and is in CPI based. } \\
\text { - Inflation is expected to have a positive relationship on } \\
\text { unemployment. } \\
\text { - Unit is in percentage. }\end{array}$ \\
\hline Population (POP) & $\begin{array}{l}\text { - Population measured by the number of persons inhabiting in a } \\
\text { country. } \\
\text { - Population is expected to have a positive relationship with } \\
\text { unemployment. } \\
\text { - Unit is in million. }\end{array}$ \\
\hline
\end{tabular}

\subsection{Methodology}

\subsubsection{Unit Root Test}

\subsubsection{Augmented Dickey-Fuller (ADF) Test}

The purpose of Augmented Dickey-Fuller (ADF) test is to check the stationarity of variables (Dickey \& Fuller, 1981). This test had been applied by Kreishan (2011) in the study of factors affecting the problem of unemployment. The equation of ADF test can be written as: 


$$
\Delta Z_{t}=\alpha s+\beta Z_{t-1}+\sum_{t=1}^{p-1} \gamma_{i} \Delta Z_{t-I}+\lambda t+\varepsilon_{t}
$$

where $\mathrm{Z}=$ time series of a variable, $\mathrm{t}=$ time trend, $\mathrm{p}=$ number of lag value and $\varepsilon=$ error term. The hypotheses for ADF unit root test are as below:

$$
\begin{aligned}
& \mathrm{H}_{0}: \beta=0 \text { (The variables are non-stationary) } \\
& \mathrm{H}_{\mathrm{a}}: \beta \neq 0 \text { (The variables are stationary) }
\end{aligned}
$$

The rejection rule for the ADF test is that the null hypothesis is rejected when the computed test statistic is greater than the critical value at a chosen significant level. This shows that the variables are stationary as well as integrated in the respective order. Conversely, if the null hypothesis is not rejected, it shows that the variables are non-stationary and the variables have a unit root. First differences are applied if a variable contains a unit root in order to make it stationary (Lal \& Lowinger, 2002).

\subsubsection{Phillips and Perron (PP) Test}

The purpose of Phillips and Perron (PP) test is to identify the existence of unit root that indirectly accounts for possible autocorrelation in disturbance term and controlling for serial correlation (Perron \& Phillips, 1987). The hypotheses for PP test are same as the ADF test written above. The equation for PP unit root test can be written as:

$$
\begin{gathered}
D Y_{t}=\alpha+\beta_{t} Y_{t-1}+\varepsilon_{t} \\
\gamma_{j}=(1 / T) \sum_{t=j+1}^{T} \varepsilon_{t}^{*} \varepsilon_{t-j}^{*} \\
W^{2}=\gamma_{0}+2 \sum_{j=1}^{q}[1-j /(q+1)] \gamma_{j}
\end{gathered}
$$

where $\mathrm{W}^{2}$ represent the Newey-west heteroskedasticity autocorrelation consistent estimation, $\gamma_{\mathrm{j}}=$ coefficient from model $(3.1), \varepsilon^{*} \varepsilon^{*}{ }_{t-j}=$ error term received from the equation, $\mathrm{q}=$ truncation lag. The same rejection rule is applied to PP test such as the ADF test above. The null hypothesis is rejected if the computed test statistic is greater than the critical value while the null hypothesis is not rejected if the computed test statistic is smaller than the critical value at a desired significant level. The next step is to proceed to first differences in order to make the non-stationary variables to become stationary. The Johansen and Juselius co-integration test will be the next step after the number of unit roots in the series had been decided.

\subsubsection{Johansen and Juselius Co-integration Test}

This econometric procedure is performed in order to examine whether the absence or presence of the long-run relationship between the variables and the number of co-integrating 


\section{Macrothink}

Journal of Public Administration and Governance

ISSN 2161-7104

2021, Vol. 11, No. 1

vectors in the particular model (Johansen \& Juselius, 1990). The Johansen and Juselius co-integration test can be explained as below:

$$
\Delta X_{t}=r_{1} \Delta X_{t-1}+r_{2} \Delta X_{t-2}+\ldots+r_{k-1} \Delta X_{t-k+1}+\prod X_{t-k=1}+\mu+\theta D_{t}+\varepsilon_{t}
$$

where $r_{1}=$ short term adjustment parameters $\left[r_{1}=-1+\prod_{1}+\prod_{2}+\ldots+\prod_{i}\right.$ for $\left.i=1,2, K-1\right]$ and $\prod$ $=$ long term equilibrium relationship independent $\mathrm{X}$ variables $\left[\Pi=-1+\prod_{1}+\prod_{2}+\ldots+\prod_{\mathrm{i}}\right.$ is an identity matrix]. $\Pi$ decomposed into the product of two $\mathrm{n}$ by $\mathrm{r}$ matrix $\alpha$ and $\beta$. Therefore, $\Pi=\alpha \beta^{*} \beta$ is a matrix contain $r$ co-integration vectors and alpha $=$ speed of adjustment parameter. Johansen and Juselius (1990) have developed two types of test statistics in examining the long run relationship between variables, namely likelihood ration trace test and maximum eigenvalue test. At most $\mathrm{r}$ co-integrating vectors, the likelihood trace test is expressed as follows:

$$
\lambda t_{r}=-T \sum_{i=q+1}^{p} \log \left(1-\lambda_{1}\right)
$$

where $T$ is the number of valid observations for estimation use and $\lambda_{\mathrm{i}}$ is the (i-th) largest estimated eigenvalue. The test hypotheses are as follows:

$\mathrm{H}_{0}$ : Number of co-integrating vector is less than or equal to $\mathrm{r}$

$\mathrm{H}_{1}$ : At most $\mathrm{r}$ co-integrating vectors $(\mathrm{r}=0,1,2, \ldots, \mathrm{p})$

The second co-integration test statistic is the maximum eigenvalue test. This test statistic is computed as:

$$
\lambda_{\max }=-T \log \left(1-\lambda_{r}-1\right)
$$

where $\mathrm{T}$ is the number of valid observation for estimation use and $\lambda_{\mathrm{r}-1}$ is the largest estimated eigenvalue at $r-1$. For this test, the null hypothesis of $r$ co-integrating vector is tested against that of the alternative of $r+1$. The rejection rule of the null hypothesis of exactly $r$ co-integrated vectors is rejected if the statistic is greater than the critical value. Therefore it proves that it has co-integrated vectors in the model suggested.

\subsubsection{Vector Error Correction Model (VECM)}

The vector error correction model (VECM) is a restricted VAR designed for use with non-stationary series that are known to be co-integrated. This model is also being used to show the short and the long run relationship between the variables. The VECM is adopted in the VAR analysis if there is a presence of co-integration in Johansen and Juselius test. In VECM, all the variables have a probability to serve as endogenous variable and it is able to distinguish the exogenous and endogenous variables. The following VECM as below:

$$
\begin{aligned}
\Delta y_{1, t} & =\alpha_{1}\left(y_{2, t-1}-\beta y_{1, t-1}\right)+\varepsilon_{1, t} \\
\Delta y_{2, t} & =\alpha_{2}\left(y_{2, t-1}-\beta y_{1, t-1}\right)+\varepsilon_{2, t}
\end{aligned}
$$


In this simple model, the only right-hand side variable is the error correction term. This term equal to zero in the long run equilibrium. However, the error correction term will be non-zero only when it differs from the long run equilibrium and each variable adjusts to partially restore the equilibrium relation. The coefficient $\alpha_{i}$ use to measures the speed of adjustment of the $(\boldsymbol{i}$-th) endogenous variable towards the equilibrium.

\subsubsection{Granger Causality}

The purpose of Granger causality test is to examine the short run causality between the variables used in the model. There are four types of possibilities direction under the test which includes: unidirectional causality (from $\mathrm{X}$ to $\mathrm{Y}$ as the dependent variable), unidirectional causality (from $\mathrm{Y}$ to $\mathrm{X}$ as the independent variable), feedback effect or bidirectional causality and independence (no direction of causality). The hypothesis testing for this test can be written as below:

$\mathrm{H}_{0}: \beta_{1}=\beta_{2}=\beta_{3}=0$ (independent variable does not Granger cause the dependent variable)

$\mathrm{H}_{\mathrm{a}}: \beta_{1} \neq \beta_{2} \neq \beta_{3}=0$ (independent variable does Granger cause the dependent variable)

The rejection rule indicates that we can reject the null hypothesis if the p-value is less than the significance level ( $\mathrm{p}$-value $\leq \alpha$ ). Subsequently, it implies that the independent variable does Granger cause the dependent variable. Apart from that, if the p-value is greater than the significance level ( $p$-value $\geq \alpha$ ) hence the null hypothesis is not rejected and it implies that the independent variable does not Granger cause the dependent variable.

\subsubsection{Variance Decomposition and Impulse Response Functions}

Variance decomposition (VDCs) is used as VECM cannot define which variables are relatively more exogenous or endogenous. Variance decomposition separates the variation in an endogenous variable into the component shocks to the VAR. Thus, the variance decomposition provides information about the relative importance of each random innovation in affecting the variables in the VAR. A variable that is optimally forecast from its own lagged values will have all its forecast error variance accounted by its own disturbance (Sims, Goldfeld, \& Sachs, 1982). On the other hand, if VDCs conclude mostly by its own shocks is deemed to be the most exogenous of all, the information of VDCs can be equivalently represented by impulse response function (IRFs). Both are designed to map out the dynamic response path of a variable due to one-period standard deviation shock to another variable. The graphical way of exposing the relative exogeneity or endogeneity of a variable can be done by IRFs (Masih et al., 2010).

\section{Results}

\subsection{Unit Root Test Results}

The purpose of unit root tests is mainly used to determine whether all the related variables are stationary or non-stationary. It is considered as the primary stage of the test before proceeding to co-integration test and vector error correction model (VECM) testing procedure in this study. Thus, this unit root test was undertaken by the use of Augmented Dickey Fully (ADF) 
as well as Phillips and Perron (PP) tests which nearly gives the consistent stationarity test conclusion. The results collected from the tests by using the software are tabulated as illustrated below:

Table 2. Unit Root Tests Results

\begin{tabular}{|c|c|c|c|c|}
\hline & \multicolumn{2}{|c|}{$\mathrm{ADF}$} & \multicolumn{2}{|c|}{$\mathrm{PP}$} \\
\hline & Intercept & $\begin{array}{l}\text { Trend and } \\
\text { Intercept }\end{array}$ & Intercept & $\begin{array}{l}\text { Trend and } \\
\text { Intercept }\end{array}$ \\
\hline & $t_{\mu}$ & $t_{\tau}$ & $\eta_{\mu}$ & $\eta_{\tau}$ \\
\hline & \multicolumn{4}{|c|}{ Level } \\
\hline LUNEM & $-1.198(0)$ & $-1.255(0)$ & $-1.530(3)$ & $-1.459(3)$ \\
\hline LGDP & $-0.749(0)$ & $-2.101(0)$ & $-0.749(0)$ & $-2.242(1)$ \\
\hline FDI & $-2.103(0)$ & $-3.752(0)^{* *}$ & $-2.003(1)$ & $-3.690(2)^{* *}$ \\
\hline INF & $1.644(0)$ & $-2.878(0)$ & $1.470(0)$ & $-2.972(3)$ \\
\hline \multirow[t]{2}{*}{ LPOP } & $-9.061(0) * *$ & $1.694(0)$ & $-7.087(3) * *$ & $1.523(2)$ \\
\hline & \multicolumn{4}{|c|}{ First Differences } \\
\hline$\triangle \mathrm{LUNEM}$ & $-4.524(0) * *$ & $-4.930(0) * *$ & $-4.578(3) * *$ & $-4.935(3) * *$ \\
\hline$\Delta \mathrm{LGDP}$ & $-4.995(0) * *$ & $-4.949(0) * *$ & $-4.995(0) * *$ & $-4.949(0) * *$ \\
\hline$\Delta \mathrm{FDI}$ & $-7.227(1)^{* *}$ & $-7.101(1) * *$ & $-16.471(28)^{* *}$ & $-17.072(28)^{* *}$ \\
\hline$\Delta \mathrm{INF}$ & $-4.872(0) * *$ & $-5.070(0) * *$ & $-4.869(3) * *$ & $-5.075(3) * *$ \\
\hline$\triangle \mathrm{LPOP}$ & $0.044(2)$ & $-4.040(0) * *$ & $-1.240(0)$ & $-4.025(2)^{* *}$ \\
\hline
\end{tabular}

Notes: The $t$ and $\eta$ statistics are for ADF and PP respectively. The subscript $\mu$ in the model allows a drift term while $\tau$ allows for a drift and deterministic trend. Refer to the main text for the notations. Asterisks $(*),(* *)$, and (***) indicate statistically significant at 10,5 , and 1 percent level respectively. Figures in parentheses are the lag lengths. The asymptotic and finite sample critical values for ADF and PP are obtained from MacKinnon (1996). All the $\mathrm{ADF}$ and PP unit root test examine the null hypothesis of a unit root against the stationary alternative. $\Delta$ denotes first difference operator.

Based on the findings in Table 2 shown above, both the ADF and PP tests showed that the $\mathrm{t}$-statistics for majority of the variables are smaller than the 5\% critical values at level form for both intercept as well as trend and intercept. Thus, the null hypothesis cannot be rejected and it can be concluded that all the variables are non-stationary at level form for both intercept as well as trend and intercept. The next step is to proceed to the first differences to identify whether the variables are stationary. This time, the t-statistics for majority of the variables are greater than the 5\% critical values hence the null hypothesis is rejected and it can be concluded that majority of the variables are stationary in the first differences for both intercept as well as trend and intercept.

In conclusion, all the variables such as LUNEM, LGDP, FDI, INF, and LPOP are considered integrated of order at first differences or I(1). Since the unit root test results indicate that all the variables have the consistent order of integration, hence this study can further proceed to the Johansen and Juselius co-integration test. 


\subsection{Johansen and Juselius Co-integration Test}

The Johansen and Juselius co-integration test is conducted to identify the existence of the long run relationship among the considered time series variables within this particular multivariate regression model. Johansen and Juselius (1990) co-integration test fundamentally depends on two forms of likelihood ratio tests, which includes the trace statistics and maximum eigenvalue to determine the number of co-integrating vectors. For this model, two lags are chosen in the selection of lag length in the VAR as it helps in avoiding the problem of serial correlation among the residual (Johansen \& Juselius, 1990). The long run equilibrium of the model in this study should be determined once the stationarity properties of all the variables were investigated. The results of the co-integration test are presented in Table 3 below.

Table 3. Johansen and Juselius Co-integration Test Results

\begin{tabular}{lccccccc}
\hline \multirow{2}{*}{ Null } & Alternative & \multicolumn{5}{c}{$\mathrm{k}=2, \mathrm{r}=1$} \\
\cline { 3 - 7 } & & \multicolumn{5}{c}{$\lambda \max$} & \multicolumn{3}{c}{ Trace } \\
\cline { 3 - 7 } & & Unadjusted & Adjusted & $95 \%$ C.V. & Unadjusted & Adjusted 95\% C.V. \\
\hline $\mathrm{r}=0$ & $\mathrm{r}=1$ & $63.455^{* *}$ & $42.986^{* *}$ & 33.877 & $129.163^{* *}$ & $87.498^{* *}$ & 69.819 \\
$\mathrm{r} \leq 1$ & $\mathrm{r}=2$ & $28.584^{* *}$ & 19.363 & 27.584 & $65.708^{* *}$ & 44.512 & 47.856 \\
$\mathrm{r} \leq 2$ & $\mathrm{r}=3$ & 20.668 & 14.001 & 21.132 & $37.124^{* *}$ & 25.149 & 29.797 \\
$\mathrm{r} \leq 3$ & $\mathrm{r}=4$ & $14.276^{* *}$ & 9.671 & 14.265 & $16.457^{* *}$ & 11.148 & 15.495 \\
$\mathrm{r} \leq 4$ & $\mathrm{r}=5$ & 2.180 & 1.477 & 3.841 & 2.180 & 1.477 & 3.841 \\
\hline
\end{tabular}

Notes: The $\mathrm{k}$ is the lag length and $\mathrm{r}$ is the co-integrating vector(s). Chosen $\mathrm{r}$ : number of co-integrating vectors that are significant under both tests. The unadjusted and the adjusted statistics are the standard Johansen statistics and the statistics adjusted for small sample correction factor according to Reinsel and Ahn (1992) methodology. Their finite sample correction multiplies the Johansen test statistic by the scale factor of $(T-p k) / T$, where $T$ is the sample size, $p$ is the number of variables, and $k$ is the lag length for the VAR model.

The null hypothesis in Johansen and Juselius co-integration test implies the model is not co-integrated $(\mathrm{r}=0)$ while the alternative hypothesis implies the model is co-integrated $(\mathrm{r}>$ 0 ). Based on the findings in Table 2 shown above, for the unadjusted trace statistics, the null hypothesis $(r=0 ; r \leq 1 ; r \leq 2 ; r \leq 3)$ are rejected at $5 \%$ significant level since the value of unadjusted trace statistics are larger compared to the 5\% critical values. The unadjusted maximum eigenvalue statistics also produced the similar results. The null hypothesis $(r=0 ; r \leq$ $1 ; r \leq 3)$ are rejected at $5 \%$ significant level since the value of unadjusted maximum eigenvalue statistics are larger compared to the 5\% critical values. This implies that there are four co-integrating vectors based on the unadjusted trace and maximum eigenvalue statistics. Since the sample size used in this study is quite small, the unadjusted trace and maximum eigenvalue statistics have to be adjusted with the finite sample correction which proposed by Reinsel and Ahn (1992). After calculating the adjustment, both the adjusted trace and maximum eigenvalue inferred that there is only one co-integrating vector since the null hypothesis of $r=0$ is rejected while the other null hypothesis cannot be rejected at $5 \%$ significant level. 
Thus, based on the adjusted trace and maximum eigenvalue statistics, it can be concluded that there is only one co-integrating vector (long run relationship) between LUNEM, LGDP, FDI, INF, and LPOP. Moreover, since both of the tests proposed that there is a presence of long run relationship hence the vector error correction model (VECM) test can be carried on to examine the number of error correction terms (ECTs).

Additionally, in ordination to figure out whether it represents actual causal factors between LUNEM and its independent variables such as LGDP, FDI, INF, and LPOP, the $\beta_{\mathrm{i}}$ matrix that consists of the parameters of co-integration vector is examined using the vector error correction estimation. The $\beta_{\mathrm{i}}$ matrix corresponds to the standardized coefficient of the variables entering into the respective co-integrating vector. The co-integrating vector for $r=1$ is utilized when normalizing with respect to the coefficient for LUNEM is given by the following equation. The normalized co-integrating coefficients with the t-statistics in obtained from EViews are shown below:

Table 4. Normalized Co-integrating Coefficients Results

\begin{tabular}{cccccc}
\hline LUNEM & LGDP & FDI & INF & LPOP & C \\
\hline 1.000 & -1.384 & -0.109 & -0.018 & 1.227 & -58.187 \\
& $(8.685)$ & $(-5.958)$ & $(-1.796)$ & $(1.379)$ & \\
\hline
\end{tabular}

Note: The number in parenthesis ( ) represents the value of t-statistics

From the normalized co-integrating coefficients results, as shown in Table 3, the long run relationship between LUNEM and its independent variables such as LGDP, FDI, INF, and LPOP can be observed. The estimated normalized equation can be written as follows:

$$
\begin{gathered}
L U N E M=58.187-1.384 L G D P+0.109 F D I+0.018 I N F-1.227 L P O P \\
(8.685) \quad(-5.958)
\end{gathered}
$$

The normalized co-integrating equation above shows that the variables of LGDP and FDI are statistically significant at the 5\% level (t-statistics > 1.96), which are consistent with theoretical expected signs, except for the variables of INF and LPOP. Both LGDP and LPOP have a negative relationship with LUNEM. On the other hand, the equation found that both FDI and INF have a direct impact towards unemployment.

The impact of LGDP exhibits a statistically significant negative influence on LUNEM, which implies that a $1 \%$ increase in LGDP will associate with a $1.384 \%$ decrease in LUNEM. It is mainly influenced by the fact that when the condition of the economy is healthy, the demand for labor increases as businesses wanted to meet the growing economy hence causing unemployment to decrease. Consistent with Okun's law which proposed by Okun (1962), where the law stated that unemployment rate declines if GDP grows rapidly. This finding was supported by Maqbool, Sattar and Bhalli (2013) and Sabir and Naz (2015), where the similar results also found in their study on Pakistan.

Moreover, the impact of FDI exhibits a statistically significant moderate positive influence on 


\section{Mll Macrothink}

LUNEM, which implies that a $1 \%$ increase in FDI will associate with a $0.109 \%$ increase in LUNEM. This indicates that the more the investment made by a company from another country which has control over the company purchased, there is a high chances that it might cause unemployment to incline. This might due to the flexibility of labor importing since some foreign investors prefer workers from their own country (Chen \& $\mathrm{Ku}, 2005$; Jaouadi, 2014). In conclusion, based on the VECM normalized co-integrating results, it is found that in the long run, LGDP and FDI are statistically significant in affecting LUNEM as compared to other variables; INF and LPOP.

\subsection{Vector Error Correction Model (VECM) Granger Causality Results}

A vector error correction model (VECM) analysis is applied once the Johansen and Juselius co-integration test has proven that there is a presence of co-integrating vector among the macroeconomic variables. This is due to the Johansen and Juselius co-integration test is not able to distinguish the direction of causality. The coefficient of error correction terms (ECTs) computed through VECM is involved to examine the causal links between the variables in the long run. In addition, ECTs principally conveys the information on the speed of adjustment and duration needed for the tested model to achieve equilibrium point. On the other hand, the Granger causality test estimates the short run relationship.

In general, two crucial information can be obtained from the analysis in Table 5 below where the first five columns simplifies the results of the Granger Causality tests while the last two columns represent the error correction terms (ECTs) which can be found from the VECM analysis. The results computed are shown as follows:

Table 5. Vector Error Correction Model (VECM) Granger Causality Results

\begin{tabular}{|c|c|c|c|c|c|c|c|}
\hline Dependent & $\triangle \mathrm{LUNEM}$ & $\Delta \mathrm{LGDP}$ & $\Delta \mathrm{FDI}$ & $\Delta \mathrm{INF}$ & $\triangle \mathrm{LPOP}$ & \multicolumn{2}{|c|}{ ECT } \\
\hline Variable & & & -statistics & & & Coefficient & t-ratio \\
\hline$\triangle \mathrm{LUNEM}$ & - & $\begin{array}{c}0.631 \\
(0.729)\end{array}$ & $\begin{array}{c}0.911 \\
(0.634)\end{array}$ & $\begin{array}{c}0.894 \\
(0.639)\end{array}$ & $\begin{array}{c}0.712 \\
(0.701)\end{array}$ & 0.189 & 0.750 \\
\hline$\triangle \mathrm{LGDP}$ & $\begin{array}{c}4.175 \\
(0.124)\end{array}$ & - & $\begin{array}{c}3.067 \\
(0.216)\end{array}$ & $\begin{array}{c}5.700 \\
(0.058)^{*}\end{array}$ & $\begin{array}{c}3.909 \\
(0.142)\end{array}$ & -0.412 & -1.923 \\
\hline$\Delta$ FDI & $\begin{array}{c}0.794 \\
(0.672)\end{array}$ & $\begin{array}{c}0.530 \\
(0.767)\end{array}$ & - & $\begin{array}{c}9.824 \\
(0.007)^{* * *}\end{array}$ & $\begin{array}{c}3.691 \\
(0.158)\end{array}$ & -4.083 & -0.974 \\
\hline$\Delta \mathrm{INF}$ & $\begin{array}{c}5.297 \\
(0.071)^{*}\end{array}$ & $\begin{array}{c}1.046 \\
(0.593)\end{array}$ & $\begin{array}{c}1.686 \\
(0.430)\end{array}$ & - & $\begin{array}{c}0.394 \\
(0.821)\end{array}$ & 1.364 & 0.780 \\
\hline$\Delta \mathrm{LPOP}$ & $\begin{array}{c}11.151 \\
(0.004)^{* * *}\end{array}$ & $\begin{array}{c}11.902 \\
(0.003)^{* * *}\end{array}$ & $\begin{array}{c}39.497 \\
(0.000)^{* * *}\end{array}$ & $\begin{array}{c}4.694 \\
(0.096)^{*}\end{array}$ & - & $-0.016^{* *}$ & -6.229 \\
\hline
\end{tabular}

Notes: The $\chi^{2}$-statistic tests the joint significance of the lagged values of the independent 


\section{Macrothink}

Journal of Public Administration and Governance ISSN 2161-7104 2021, Vol. 11, No. 1

variables, and the significance of the error correction term(s). $\Delta$ is the first different operator. Asterisks $(*),(* *),(* * *)$ indicate statistically significant at 10,5 , and 1 percent level respectively.

First and foremost, the selection of the precise ECT must fulfil all the three rule of thumbs, in which the coefficient of ECT must be negative in value, less than one, and significant (t-ratio > 1.96). Conversely, if one of the conditions fails to be fulfilled, the whole VECM is considered to be invalid or inadequate. As an illustration, the model will be considered as inadequate even if t-ratio is significant but the coefficient of ECT is greater than one. Briefly, it is very crucial in getting the precise and significant ECT as it can show the long run causal relationship between the variables and its coefficient will be able to specify the speed of adjustment of the estimated model.

Based on the findings in Table 5 above, the VECM analysis indicates that the ECT of LPOP fulfils all these rule of thumbs. ECT suggests that $\triangle$ LPOP bear the burden of short run adjustment to bring about the long run equilibrium. The coefficient of ECT for $\triangle \mathrm{LPOP}$ is -0.02 and it is statistically significant at $5 \%$ level as its t-ratio is -6.23 which is larger than the critical value of 1.96 . The speed of adjustment is about $2 \%$ per year. This implies that Malaysia will need approximately 50 years to adjust back to equilibrium whenever disequilibrium happens. Furthermore, in the long run condition, the model reveals that there are four unidirectional causalities, which runs from LUNEM, LGDP, FDI, and INF to LPOP. Figure 4.1 exhibits the overall direction of the long run causal relationship between the five considered variables.

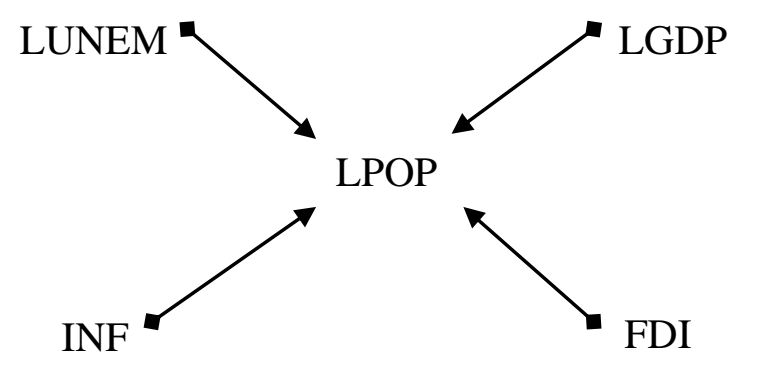

Direct:

a) LUNEM $\rightarrow$ LPOP

b) LGDP $\rightarrow$ LPOP

c) $\mathrm{FDI} \rightarrow \mathrm{LPOP}$

d) INF $\rightarrow$ LPOP

Figure 1. Long Run Causality Direction

As for the Granger causality test in Table 5 shown above, there is no short run relationship between the fundamental macroeconomic factors and unemployment when LUNEM acts as the dependent variable. Figure 2 indicates the short run direction of the Granger causality 
relationship between the variables.

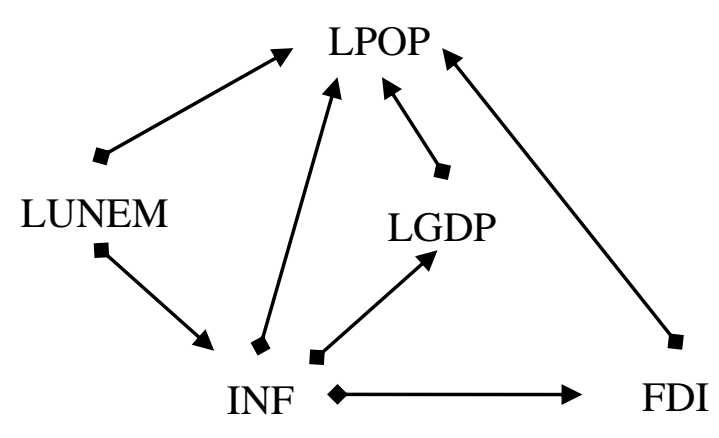

Direct:
a) INF $\rightarrow$ LGDP
b) INF $\rightarrow$ FDI
c) INF $\rightarrow$ LPOP
d) FDI $\rightarrow$ LPOP
e) LGDP $\rightarrow$ LPOP
f) LUNEM $\rightarrow$ INF
g) LUNEM $\rightarrow$ LPOP

Indirect:

a) LUNEM $\rightarrow$ LPOP

Figure 2. Short Run Causality Direction

There are seven short run causalities when the other variables act as the dependent variable, detected at $1 \%$ and $10 \%$ significant level. In the short run condition, the Granger causality test results showed that all the variables are involved in the short run association causing seven unidirectional causality relationship running from; (i) INF to LGDP; (ii) INF to FDI; (iii) INF to LPOP; (iv) FDI to LPOP; (v) LGDP to LPOP; (vi) LUNEM to INF; and (vii) LUNEM to LPOP. Moreover, there are also two indirect causality relationship running from LUNEM to LPOP and INF to LPOP.

\subsection{Dynamic Analysis Results}

This section is principally aimed to further provide the indication of dynamic properties of the system. It is applied to recover the weaknesses of VECM where it only indicates the Granger causality information among the variables within the sample period. The findings by Masih and Masih (1996) suggested that to estimate the relative strength of the variables and the transmission mechanism response beyond the observed sample or simply known as the out of sample, the system was shocked and separated the forecast error variance decomposition for each of the variables in the system. Thus, variance decompositions (VDCs) and impulse response functions (IRFs) were utilized under this dynamic analysis. Both tests are executed using time horizons of 1 to 50 years.

\subsubsection{Variance Decomposition (VDCs)}

As mentioned earlier, the variance decomposition (VDCs) is adopted to identify the relative strength of the variables when the variables are shocked. The last row of each bold column provides the percentage of forecast error variances of each variable explained jointly by the other variables at the end of the 50 year horizon. Furthermore, the estimated error variances can be applied to find out whether the variable is the most endogenous or the most exogenous, which depends on the impact of shock caused by its own factor and the impact of other 
variables influence on it. Tables 6 shows the results of variance decomposition on natural logarithm of unemployment (LUNEM), natural logarithm of gross domestic product (LGDP), foreign direct investment (FDI), inflation (INF), and natural logarithm of population (LPOP).

Table 6. Variance Decomposition Results

\begin{tabular}{|c|c|c|c|c|c|c|c|}
\hline \multirow{2}{*}{$\begin{array}{l}\text { Percentage } \\
\text { of } \\
\text { variations } \\
\text { in }\end{array}$} & \multirow{2}{*}{$\begin{array}{l}\text { Horizon } \\
\text { (Years) }\end{array}$} & \multicolumn{6}{|c|}{ Due to Innovation in: } \\
\hline & & $\triangle \mathrm{LUNEM}$ & $\Delta$ LGDP & $\Delta$ FDI & $\Delta \mathrm{INF}$ & $\Delta \mathrm{LPOP}$ & $\Delta \mathrm{CU}$ \\
\hline \multicolumn{8}{|c|}{ Quarters Relative Variance in: $\triangle$ LUNEM } \\
\hline & 1 & 100.0000 & 0.000000 & 0.000000 & 0.000000 & 0.000000 & 0.000000 \\
\hline & 10 & 96.21112 & 0.309519 & 0.487559 & 2.297383 & 0.694418 & 3.78888 \\
\hline & 20 & 95.15055 & 0.276798 & 0.653287 & 2.973772 & 0.945595 & 4.84945 \\
\hline & 30 & 93.27933 & 0.772942 & 1.350860 & 3.148022 & 1.448850 & 6.72067 \\
\hline & 40 & 88.21700 & 1.251518 & 3.291855 & 4.421772 & 2.817854 & 11.78300 \\
\hline & 50 & 77.89222 & 1.991694 & 7.343131 & 6.209981 & 6.562973 & 22.10778 \\
\hline \multicolumn{8}{|c|}{ Quarters Relative Variance in: $\Delta$ LGDP } \\
\hline & 1 & 41.53812 & 58.46188 & 0.000000 & 0.000000 & 0.000000 & 41.53812 \\
\hline & 10 & 30.44828 & 58.21632 & 2.920365 & 3.623951 & 4.791086 & 41.78368 \\
\hline & 20 & 26.52876 & 53.32365 & 6.182628 & 5.228695 & 8.736269 & 46.67635 \\
\hline & 30 & 20.71879 & 43.27622 & 13.07739 & 7.975432 & 14.9 & 56.72378 \\
\hline & 40 & 14.33318 & 27.56800 & 21.64190 & 13.60750 & 22.8 & 72.43200 \\
\hline & 50 & 8.643647 & 13.72704 & 30.43047 & 18.11148 & 29.08736 & 86.27296 \\
\hline \multicolumn{8}{|c|}{ Quarters Relative Variance in: $\Delta \mathrm{FDI}$} \\
\hline & 1 & 38.18400 & 13.00012 & 48.81587 & 0.000000 & 0.000000 & 51.18413 \\
\hline & 10 & 23.47235 & 18.55151 & 29.80258 & 14.42896 & 13.74460 & 70.19742 \\
\hline & 20 & 11.05663 & 17.32853 & 31.58034 & 15.34451 & 24.68999 & 68.41966 \\
\hline & 30 & $7.237 \xi$ & 10.76121 & 34.93825 & 15.56223 & 31.50046 & 65.06175 \\
\hline & 40 & 5.423395 & 7.632 & 35.00327 & 17.03249 & 34.90795 & 64.99673 \\
\hline & 50 & 5.733685 & 5.043201 & 34.87726 & 19.00835 & 35.33751 & 65.12274 \\
\hline \multicolumn{8}{|c|}{ Quarters Relative Variance in: $\Delta \mathrm{INF}$} \\
\hline & 1 & 4.260084 & 0.676974 & 4.731631 & 90.33131 & 0.000000 & 9.66869 \\
\hline & 10 & 17.91563 & 1.494848 & 2.353404 & 77.45536 & 0.780763 & 22.54464 \\
\hline & 20 & 10.46234 & 1.910733 & 2.839025 & 83.09143 & 1.696470 & 16.90857 \\
\hline & 30 & 9.503690 & 3.903943 & 6.766654 & 76.08292 & 3.742791 & 23.91708 \\
\hline & 40 & 12.05 & 5.617 & 11.87354 & 61.82834 & 8.628032 & 38.17166 \\
\hline & 50 & 12.74050 & 6.232896 & 21.99688 & 42.24645 & 16.78327 & 57.75355 \\
\hline \multicolumn{8}{|c|}{ Quarters Relative Variance in: $\triangle \mathrm{LPOP}$} \\
\hline & 1 & 2.132029 & 8.558008 & 51.59102 & 0.914888 & 36.80406 & 63.19594 \\
\hline & 10 & 62.88866 & 17.75370 & 16.67462 & 1.741794 & 0.941222 & 99.05878 \\
\hline & 20 & 69.38769 & 16.52954 & 11.33684 & 2.315551 & 0.430372 & 99.56963 \\
\hline & 30 & 69.96615 & 16.31443 & 10.67568 & 2.459097 & 0.584644 & 99.41536 \\
\hline & 40 & 70.20753 & 15.61612 & 10.16730 & 3.000205 & 1.008836 & 98.99116 \\
\hline & 50 & 68.21130 & 15.65233 & 10.65517 & 3.295293 & 2.185914 & 97.81409 \\
\hline
\end{tabular}

Notes: The last column provides the percentage of forecast error variances of each variable explained collectively by the other variables. The column in bold represents the impact of their own shock.

Based on the results shown above, it indicates that about $78 \%$ of LUNEM's forecast error variance can be explained by its own shock while $2 \%$ by LGDP, $7 \%$ by FDI, $6 \%$ by INF, and $7 \%$ by LPOP at the end of 50 years horizon. The cumulative percentage of the forecast error variance for LUNEM being explained by other variables is about $22 \%$. 


\section{Macrothink}

For LGDP, about $14 \%$ of the forecast error variance can be explained by its own shock meanwhile $9 \%$ by LUNEM, $30 \%$ by FDI, $18 \%$ by INF, and $29 \%$ by LPOP at the end of 50 years horizon. The cumulative percentage of LGDP being explained by other variables is about $86 \%$. In addition, FDI can be explained by its own shock in about $35 \%$. On the other hand, LUNEM, LGDP, INF, and LPOP can explain FDI by 6\%, 5\%, 19\%, and 35\% respectively at the end of 50 years horizon. The cumulative percentage of the forecast error variance for FDI being explained by other variables is 65\%. Furthermore, INF can be explained in about $42 \%$ by its own shock while $13 \%$ by LUNEM, $6 \%$ by LGDP, $22 \%$ by FDI, and $17 \%$ by LPOP at the end of 50 years horizon. The cumulative percentage of INF being explained by other variables is $58 \%$. Last but not least, LPOP can be explained by $2 \%$ of its own shock meanwhile 68 percent, 16\%, 11\%, and 3\% by LUNEM, LGDP, FDI, and INF respectively at the end of 50 years horizon. The cumulative percentage of LPOP being explained by other variables is $98 \%$.

In conclusion, it is proven that LPOP is the most endogenous (most explained by shock of others) variable. Besides that, LUNEM is the most exogenous (least explained by shock of others) variable in the system with only about $22 \%$ of its forecast variance being explained by the remaining variables in the entire forecast horizon. In the other words, the reason regarding the LUNEM is categorized as the most exogenous variable is that the shock caused by the other variables only brings an impact of $22 \%$ on it, while another $88 \%$ was caused by itself which can be implied that LUNEM does not depend much on other variables. However, LPOP indicates it depends much on other variables or it can be described that LPOP act as the dependent variable in the system.

\subsubsection{Impulse Response Functions (IRFs)}

Impulse response functions (IRFs) analysis was conducted to illustrate the beyond sample dynamic relationship and to show the response of a variable to a "shock" in itself or another variables in the system over the time. In a three dimensional variables, there are 25 possible scenarios of IRFs for each of variable is constructed separately. Visual illustrations of the IRFs up to 50 years are presented in Figure 3. The variables are rather sluggish but able to settle after 15 years horizon. 

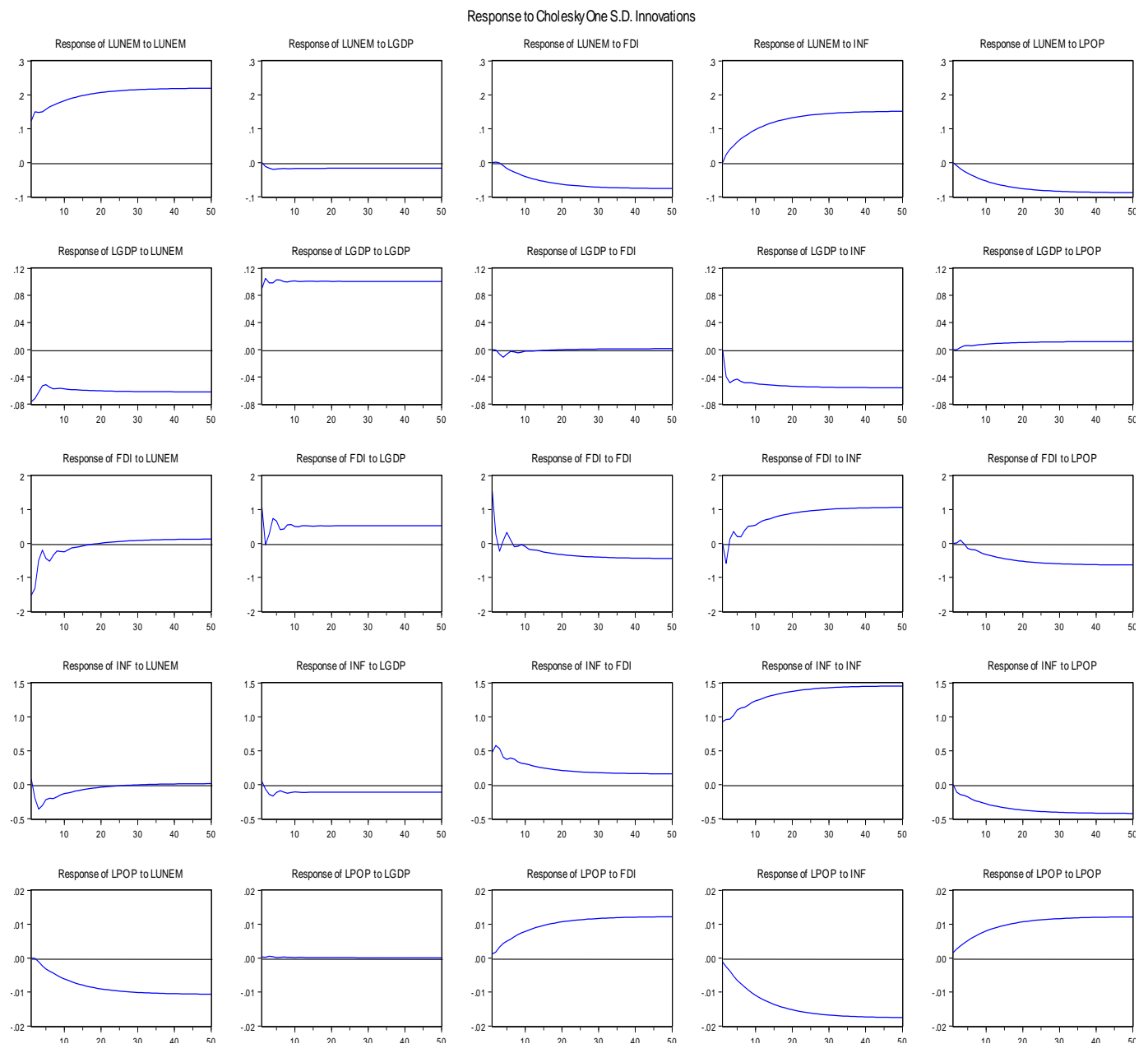

Figure 3. Impulse Response Functions (IRFs)

The variables are rather sluggish but able to settle after 15 years interval. LUNEM responded negatively to the shock in LGDP, FDI, and LPOP implying the existence of a negative relationship between them. LGDP also responded negatively to the shock in LUNEM and INF implying the negative relationship with LUNEM and INF. In addition, FDI responded negatively to the shock in FDI itself and LPOP as well implying the presence of negative relationship between them. The same goes to INF which responded negatively to LGDP and LPOP while LPOP responded negatively to LUNEM and INF. Other than the negative response mentioned, all the results presented here indicate that the rest of the variables have positive relationship among each other. Besides the own shock, other determinants will affect LUNEM. The shock on LUNEM will bring impact towards other determinants, which are LGDP, FDI, INF, and LPOP. Thus, there is a causal relationship between LUNEM and the other determinants beyond the sample.

\section{Discussion}

This study essentially aims to examine the relationship between unemployment and the fundamental macroeconomic factors in Malaysia from the year 1985 to 2015. The variables used in this study are unemployment (UNEM), gross domestic product (GDP), foreign direct 
investment (FDI), inflation (INF), and population (POP). The findings indicating that there is a presence of one co-integrating vector or in other words, there is a long run relationship between the selected macroeconomic variables in this study. There is a long run relationship within the model only when LPOP acts as the dependent variable. It also shows that LPOP bear the burden of short run adjustment to bring about the long run equilibrium and the speed of adjustment is about $2 \%$ per year, implying that Malaysia will need approximately 50 years to adjust back to equilibrium whenever disequilibrium happens. On the other hand, , it is found that in the long run, LGDP and FDI are statistically significant in affecting LUNEM as compared to other variables; INF and LPOP. As for the short run relationship, there are seven unidirectional causality relationship running from; (i) INF to LGDP; (ii) INF to FDI; (iii) INF to LPOP; (iv) FDI to LPOP; (v) LGDP to LPOP; (vi) LUNEM to INF; and (vii) LUNEM to LPOP. Moreover, there are also two indirect causality relationship running from LUNEM to LPOP and INF to LPOP. Last but not least, dynamic analysis shows that LPOP is the most endogenous variable (most explained by shock of others) while LUNEM is the most exogenous variable (least explained by shock of others) in the model. Additionally, IRFs illustrate the beyond sample dynamic relationship and to show the response of a variable to a "shock" in itself or another variables in the system over the time and the result shows that the rest of the variables have positive relationship among each other plus there is a causal relationship between LUNEM and the other determinants beyond the sample.

As youth (fresh graduates) are among the groups contribute to the higher rate of unemployment, they are encouraged to learn how to build their integrity, be competitive and responsible. A program such as 1MalaYSIA Training Scheme (SL1M), which was launched since June 2011 could be the platform to train fresh graduates. Until now, more than 97,000 graduates have benefited through the program and found jobs after they attended job training and improving their communication skills. In addition, government could encourage and promote young entrepreneurship as a way of creating new products and market demand which may generate new employment opportunities, such as conducting a carnival, campaign, and etc. In rural areas, it is suggested for government or stakeholders to provide more development of new land which can contribute fund to the people for farming, fishing and agriculture skills.

At macro level, based on the findings obtained, the relationship between unemployment and the chosen fundamental macroeconomic factors are identified either in the short run or long run. Therefore, certain relevant policy may be recommended in helping the country to overcome and handle the problem of unemployment. There are two main policies for reducing unemployment which are demand side policies and supply side policies (Lindbeck $\&$ Snower, 1990). The result implies that there is strong statistical evidence which indicates that when GDP increases, unemployment can be reduced (Okun, 1962). Malaysian government and policy makers should consider implementing demand side policies such as fiscal policy and monetary policy.

Through fiscal policy, unemployment can be reduced by increasing the aggregate demand and economic growth rate. The government will need to practise expansionary fiscal policy which involves increasing the government's spending and cutting taxes. As a result, lower 
taxes help to increase disposable income consequently consumption will increase and leads to higher aggregate demand. With an increase in aggregate demand, real GDP will increase as well. In addition, the demand for workers will increase if firms produce more thus lowering demand deficient unemployment (Pettinger, 2016). Besides, once the country's aggregate demand is high and the economic growth rate is strong, fewer firms will go bankrupt in sense fewer job losses. In term of monetary policy, unemployment can be reduced by cutting interest rates (Friedman, 1968; Pettinger, 2016). Lower interest rates encourage people to spend and invest more as the cost of borrowing is decreased. Hence, this indirectly increases aggregate demand and GDP which eventually reduce demand deficient unemployment. Subsequently, the result obtained also indicates that there is significant moderate positive relationship between unemployment and FDI. In order to overcome this problem, Malaysian government should execute supply side policies. Although it deal more on microeconomic issues however it seek to trounce weaknesses in the labor market and lessen unemployment caused by the supply side factors. As mentioned before, some foreign investors prefer workers from their own country due to flexibility of labor importing (Chen \& $\mathrm{Ku}, 2005$; Jaouadi, 2014).

However, Malaysia is actually on the right path in tackling this problem which is by giving education and training to youth especially fresh graduates as well as workers with no experiences. 1 Malaysia Training Scheme which is also known as Skim Latihan 1 Malaysia (SL1M) was introduced by the government on $1^{\text {st }}$ June 2011 (Economic Planning Unit, 2011). The main aims of this training programme is to help unemployed young graduates to develop their marketability and employability with the proper skills, knowledge, and working experiences throughout the training in order to increase their opportunity in advancing their career in the future which at the same time reduce unemployment rate and compete with foreign labor. Participants of SL1M will be undergoing soft skills and on the job training with the participating company. Through soft skills training, participants will be exposed to five compulsory modules which are communication, creative and analytical thinking, organizational adaptability, value driven professional, as well as grooming and etiquette. On the other hand, on the job training will expose participants to real working environment (Economic Planning Unit, 2011; Shamsuddin et al, 2013).

\section{References}

Ali, S., Ali, A., \& Amin, A. (2013). The Impact of Population Growth on Economic Development In Pakistan, 18, 483-491.

Altig, D., Fitzgerald, T., \& Rupert, P. (1997). Okun's law revisited: should we worry about low unemployment? (pp. 1-4). Ohio: Federal Reserve Bank of Cleveland.

Blinder, A. S. (1997). A core of macroeconomic beliefs?. Challenge, 40(4), 36-44. https://doi.org/10.1080/05775132.1997.11471984

Burns, A. F. (1969). The Problem of Unemployment. The Business Cycle in a Changing World. Cambridge: National Bureau of Economic Research.

Chen, T. J., \& Ku, Y. H. (2000). The effect of foreign direct investment on firm growth: the 
case of Taiwan's manufacturers. Japan and the World Economy, 12(2), 153-172. https://doi.org/10.1016/S0922-1425(99)00035-3

Dickey, D. A., \& Fuller, W. A. (1979). Distribution of the estimators for autoregressive time series with a unit root. Journal of the American statistical association, 74(366a), 427-431. https://doi.org/10.1080/01621459.1979.10482531

El-Agrody, N. M., Othman, A., Bahaa, M., \& Hassan, E. (2010). Economic Study of Unemployment in Egypt and Impacts on GDP. Nature and Science, 8(10), 102-111

Hanapi, Z., \& Nordin, M. S. (2014), Unemployment Among Malaysia Graduates: Graduates' Attributes, Lecturers' Competency And Quality Of Education, Procedia-Social and Behavioral Sciences, 112, 1056-1063. https://doi.org/10.1016/j.sbspro.2014.01.1269

Jaouadi, S. (2014). Could Foreign Direct Investment Increase Unemployment: Case Of KSA. Research Journal of Economics and Business Studies, 3, 51-56.

Johansen, S., \& Juselius, K. (1990), Maximum Likelihood Estimation and Inference On Cointegration - With Applications To The Demand For Money. Oxford Bulletin of $\begin{array}{llll}\text { Economics } \quad \text { and } & \text { Statistics, } & \text { 169-210. }\end{array}$ https://doi.org/10.1111/j.1468-0084.1990.mp52002003.x

Kreishan, F. (2011). Economic Growth and Unemployment: An Empirical Analysis. Journal of Social Sciences, 7(2), 228-231. https://doi.org/10.3844/jssp.2011.228.231

Lal, A. K., \& Lowinger, T. C. (2002). Nominal Effective Exchange Rate And Trade Balance Adjustment in South Asia Countries. Journal of Asian Economics, 13(3), 371-383. https://doi.org/10.1016/S1049-0078(02)00120-3

Lindbeck, A., \& Snower, D. (1990). Demand- and Supply-side Policies and Unemployment: Policy Implications of the Insider-Outsider Approach. Scandinavian Journal of Economics, 92(2), 280-305. https://doi.org/10.2307/3440032

MacKinnon, J. G. (1996), Numerical Distribution Functions for Unit Root and Cointegration Tests, Journal of Applied Econometrics, 11, 601-618. https://doi.org/10.1002/(SICI)1099-1255(199611)11:6<601::AID-JAE417>3.0.CO;2-T

Maqbool, M. S., Sattar, A. T. M., \& Bhalli, M. N. (2013). Determinants of Unemployment: Empirical Evidences from Pakistan. Pakistan Economic and Social Review, 51(2), 191-207.

Masih, M., Alsahlawi, M., \& DeMello, L. (2010). What drives Carbon-dioxide Emissions: Income or Electricity Generation? Evidence from Saudi Arabia. The Journal of Energy and Development, 33(2), 201- 213.

MIDF Research (2016). Increase in Malaysia's Unemployment Rate Trend. Retrieved June 22 , 2017 from https://www.astroawani.com/berita-bisnes/increase-in-malaysias-unemployment-rate-trend-m idf-research-94955

Mpanju, A. (2012). Employment Impact of Foreign Direct Investment, Lambert, Academic 
Publishing.

Mucuk, M., \& Demirsel, M. T. (2013). The Effect Of Foreign Direct Investments On Unemployment: Evidence From Panel Data For Seven Developing Countries, Journal of Business, Economics \& Finance, 2(3), 53-66.

Natrass, N. (2002b). Should Youth Employment be targeted as a Part of a Comprehensive Welfare Policy in South Africa? Social Dynamics, 28(2), 207-236. https://doi.org/10.1080/02533950208458738

Okun, A. (1962). Potential GNP: Its measurement and Significance, American Statistical Association: Proceeding of the Business and Economics Statistics Section.

Pettinger, T. (2016). Policies for reducing unemployment. Retrieved February 27, 2017, from http://www.economicshelp.org/ blog/3881/economics/policies -for-reducing-unemployment/

Phillips, P., \& Perron, P. (1986). Testing for a Unit Root in Time Series Regression. Cowles Foundation, Yale University, Cowles Foundation Discussion Papers, 75.

Prachowny, M. (1993). Okun's Law: Theoretical Foundations and Revised Estimates. The Review of Economics and Statistics, 75, 331-336. https://doi.org/10.2307/2109440

Rafiq, M., Ahmad, I., Ullah, A., \& Khan, Z. (2010). Determinants of Unemployment: A Case Study Of Pakistan Economy (1998-2008), Abasyn Journal of Social Sciences, 3(1).

Sabir, G. M., \& Naz, S. (2015). Economic Determinants of Unemployment: Empirical Result from Pakistan. Journal of Economics and Sustainable Development, 6(9), 150-154.

Şahin, D., Enflasyon, G., Yabancı, O. V., Yatırımları, S., Kısa, B., Sonuçları, D., Içi, G. S., \& Yurt, G. S. (2016). Determinants of Unemployment: Empirical Analysis For China.

Shaari, M., Hussain, N., \& Halim, A. M. S. (2012). The Impact of Foreign Direct Investment on the Unemployment Rate and Economic Growth in Malaysia. Journal of Applied Sciences Research, 8, 4900-4906.

Shamsuddin, A., \& Mohmad, K., Naim, M., \& Nafisah, Z., Mahfol, M., \& Alagari, T. (2013). Graduate Unemployment: The Awareness And Perception Of Graduates Towards Government's Initiatives. International Journal Of Business, Economics And Law, 3, 15-24.

Sims, C., Goldfeld, S., \& Sachs, J. (1982). Policy Analysis with Econometric Models. Brookings Papers on Economic Activity, 1982(1), 107-164. https://doi.org/10.2307/2534318

Subhani, M., Imtiaz, O., \& Amber, N. M. (2011). The South Asian Phillips Curve: Assessing the Gordon Triangle. European Journal of Economics Finance and Administrative Science, 114(36), 110

Trimurti, C. P., \& Komalasari, Y. (2014), Determinants of Unemployment: Empirical Evidences from 7 Province in Indonesia, Scientific Research Journal (SCIRJ), 2(8), 5-9.

Umair, M., \& Ullah, R. (2013). Impact of GDP And Inflation On Unemployment Rate: A Study Of Pakistan Economy In 2000-2010, International Review of Management And 
Business Research, 2(2).

Zaleha, M. N., Noraini, I., Rusmawati, S., \& Suhaila, A. J. (2011). The Impact of Foreign Workers on Labour Productivity in Malaysian Manufacturing Sector, International Journal of Economics and Management, Universiti Putra Malaysia.

\section{Copyright Disclaimer}

Copyright for this article is retained by the author(s), with first publication rights granted to the journal.

This is an open-access article distributed under the terms and conditions of the Creative Commons Attribution license (http://creativecommons.org/licenses/by/4.0/). 